\title{
COVID-19: A STRIFE OF INTERESTS FOR US ALL AND WHAT PROBLEM ARE WE ATTEMPTING TO SOLVE?
}

\author{
DS Briggs AM \\ Editor in Chief
}

At the time of writing, nation states globally are beginning the vaccination process in response to Covid-19. There is great expectation that it will deliver effective protection to most populations. The logistic of the production and delivery of the vaccines, and use are immense and, we are fortunate, in the Australian context that the extent of the virus spread, and impact has been relatively limited and mostly contained. While everyone is wanting rapid progress, our context does allow us the opportunity to 'hasten slowly' and have a positive outcome.

This development will require the continuation of the considered and reassuring engagement of the Australian Prime Minister, his health minister, The chief health adviser, and departmental staff directly with the Australian community. This has been a feature of our national response so far. This has been a unique and innovative approach to the political governance process seen in Australia. That same approach has not been seen to be as effective across most state and territory jurisdictions, despite the innovative use of a national cabinet that is inclusive of their ability to participate in sensible decision making. In fact, it is emphasised that:

systems for health require substantive community engagement at every step of pandemic preparedness and response, from early detection and alarm, to the dissemination of reliable information throughout a community... [5 p.23]

The state of NSW has mostly been the exception to the disarray at that level and despite some early backsteps has delivered a strong, well-resourced public health response based on testing tracing and isolating in limited fashion, with mostly limited geographic lockdown when required. That State has also shouldered a major responsibility for processing international returning travellers many of whom were residents of the others states.

States and territories in differing contexts may require different approaches but some of those have also appeared to be parochial and populist. There has been criticism and blame of others and even 'boasting' of individual state performances. The prime example in my opinion was to claim that hospitals in one state were for residents of that state only and not for others. This is a dishonest claim when hospitals, across Australia are jointly funded by the Commonwealth and States and their role, providing universal access is enshrined in healthcare agreements. In addition, Australia has signed agreements with other nation states that allows access to health systems and vice versa when our citizens are travelling in and visiting our respective countries.

That claim also ignores the data and evidence that a tenyear analysis of linked hospital data demonstrates on average that between $3 \%$ and $5 \%$ of patients within one state had hospital records in another state and that between $4 \%$ and $7 \%$ of hospital records occurring in a state can be attributed to an individual who has a record in another state. [1] This claim also ignores the extant border flows for healthcare, employment and commerce and the internal flow of patients within states and regions. While individuals and families were denied border access and denied access to care, families, births and weddings, the masses were entertained by border crossing professional sports team, complete with crowds in attendance and at least one professional sport group were deemed 'essential workers'!

While we as individuals in Australia wonder about why the debate at state/territory level with distinctions based on 
historical lines on a map is to say the least discordant, McKee and colleagues [2] in a European context argues that populist leaders have 'undermined the pandemic responses'. [2, p.1] They instance those elected to power on populist agendas as in the United States, Brazil, Russia, India and the United Kingdom, have tended to blame "others" While China denies evidence 'and shows contempt for organisations that generate it.' [2, p.1] These authors ask that if politicians 'wilfully ignore scientific evidence that goes against their political strategy or ideology is that lawful?'. [2 p.1] Kamran Abbasi, the executive editor of the BMJ acknowledges some two million deaths globally, takes the matter further suggesting criminality and culpability for those who have failed in their respective pandemic responses. He sees the accountability in international contexts with 'hollow responses from national and international leaders'. He further questions 'where do citizens turn for accountability?' [3, p1,2]

In defence of politicians, they could equally instance conflicting scientific advice and the good contribution of scientists in the media, properly evidences differing scientific views. They might also argue that their charter extends beyond healthcare to the wider economic wellbeing of the population and the economy.

Bollyky and Kickbusch suggests the context 'requires politicians to set aside ideology and act on a rapidly emerging and uncertain body of public-health evidence'. The context is less to do with coronavirus but what it has 'revealed about the political systems that have responded to it'. [4, p.2] While finding some democracies to be failing in their response to the pandemic, they describe the many beneficial contributions between democracies and improved healthcare outcomes. They cite lower death rates in infants and children younger than 5 years, and with longer life expectancy at birth, lower mortality from causes such as cardiovascular disease and reduced transport injuries. They emphasise that these successes in democracies depend on 'robust health infrastructure.' [4, p.1]

The Independent Panel for Pandemic Preparedness [5] found that 'the world was not prepared for the pandemic, and must do better' and goes on to suggest that:

The public health measures which would curb the pandemic need to be applied comprehensively, the pandemic response has deepened inequalities. The global pandemic alert system is not fit for purpose and there has been a failure to take seriously the already known existential risks posed by pandemic threat. The $\mathrm{WHO}$ has been underpowered to do the job expected of it and the Panel believes that the COVID-19 pandemic must be a catalyst for fundamental and systemic change in preparedness for future such events, from the local community right through to the highest international levels. [5]

The Panel observed that:

choices made at both national and sub-national levels of what policies and measures to implement, by whom, and when, have shaped the severity of the epidemic in each country... The public health measures which would curb the pandemic need to be applied comprehensively. [5, p.20,)

An editorial built around the precepts of structural interest theory $[6,7]$ would be remiss if it did not also recognise the role of communities and the media that are also part of the 'strife of interests' [8] which these days has emerged as a view of healthcare as 'complex adaptive systems'. [9]

As for the citizens, McKee and colleagues ask If citizens feel disempowered, how might they hold negligent politicians to account? [2 p.16] The editor is an adherent to the adage that 'the electorate usually gets it right'! Yet in a recent Australian state election the populist parochial approach won the election! Apparently that population felt that they were being well protected from Covid -19 and presumably from the rest of us. This is consistent with findings in other countries where voters 'did not blame their governments'. [4] This then goes to the psyche of communities and populations in democracies where we assume, they are resilient, independently minded and who value their freedoms and liberties.

It is said that 'populism and nationalism feed off the threat of the virus and question the reliability of science and information and is an entry point for autocratic governments to change laws and introduce restrictions'. [4, p.1] There is little evidence that supports a single characteristic of government or society ensuring better performance in a pandemic. [4] These same authors cite the German Chancellor Angela Merkel in a 2020 television address who emphasised that she spoke as the head of a democracy in which citizens 'do not live by coercion, but by shared knowledge and participation'. [4, p.1.9] 
Merkel goes on to suggest that the German response will depend on collective actions and solidarity. She further emphasises her personal history of living more than half her life in the former East Germany, behind the 'Berlin Wall' where her movements were constrained by the state. Merkel emphasises that the 'freedom to travel was a hard fought for right and such restrictions can only be justified if they are an absolute necessity'... they should never be passed lightly and only ever temporarily...but are indispensable now to save lives.' [4]

Another media perspective [10] suggests the hesitancy of populations reflects an increased aversion to risk in both social behaviour and in the words, we use to the extent that it now reflects a demand to eliminate uncertainty. This becomes a task not just for government but for 'experts' and institutional regulation in public health that has had profound implications for social attitudes. Ergas [10] concludes that 'authority once gained is not readily relinquished.'

A former Australian Foreign Minister, according to Albrechtsen [11], has a stern warning for the 'lockdowners'. Working in both the United Kingdom and Australia he has an appreciation of differing national approaches and he considers that we do not have a sensible exit plan. He concedes that Australia has done very well but warns that an 'elimination strategy will never work'. Albrechtsen [11] further quotes him as saying.

'he says, firmly'. "The public need to reflect on how we manage the risk of these kinds of pandemics. You have to keep - society going. You have to keep schools open. You can't keep closing things down because there is a case here and a case there."

In the article he describes his reception at Tullamarine airport on arrival as being asked by the police for them to see his 'papers'. He laments that this is Australia and people think this increased security 'is wonderful.' His 'point is that it is not sustainable. We've got to start thinking about managing the risk.' He adds 'the rise in mental health problems, the destruction of social contact," he says. "In Australia? No debate. What explains this? Fear? complacency? Poor leadership?' [11]

Some emphasise the importance of the link between democracy and health is greater freedom of expression but at the same time cite a view that 'social media disinformation campaigns exploit the openness of democracies, erode their health benefits...' $[4, p .1,12]$ Put more simply a post from Facebook delivered at a time when that media has wilfully determined to exclude access to news to Australians on Facebook, nonetheless a worthy quote comes from Blanca Estela Castro 'the truth is still the truth, even if no one believes it. A lie is still a lie, even if everyone believes it.' [13]

The Covid-19 pandemic presents an active case study for those interested in observing or studying structural interests in play and is an excellent opportunity for students and academics to research and inform curriculum and training of health professionals. It also is an opportunity for all of us to exercise some reflection on how we best engage the political and policy governance of health systems to invest in a civil society that values good health and personal engagement in getting it right. We need to encourage less fear 'strengthen social solidarity and address societal inequalities while strengthening legitimacy of trust and values generally'.[4]

In conclusion I suggest that the important questions to ask in these contexts is 'what problem are we attempting to solve and whose interests are being served?' [14]

\section{DS Briggs AM}

Editor in Chief

\section{References}

1. Boyd JH. Randall SM. Ferrante AM. Baver, JK. McInneny. AP. Brown, KS. Gillies M. Semmens JB. (2015). Accuracy and completeness of patient pathways - the benefits of national data linkage in Australia. Boyd et al. BMC Health Services Research (2015) 15:312. DOI 10.1186/s12913-015-0981-2.

2. McKee M. Gugushvili A. Koltai J. Stuckler D. (2020). Are populist leaders creating the condition for the spread of Covid-19? Comment on 'a scoping review of populist radical right parties' influence on welfare policy and its implications for population health in Europe' International Journal of Health Policy and Management, 2020, x(x), 1-5.

3. Abbasi K. (2021). Social murder, they wrote-elected, unaccountable, and unrepentant after two million deaths, we must have redress for mishandling the pandemic. BMJ 2021;372: n314 
http://dx.doi.org/10.1136/bmj.n314 Published: 04 February 2021.

4. Bollyky TJ. Kickbusch I. (2020). Democracy and health. Preparing democracies for pandemics. Tackling inequalities is essential for justice, security, and preparedness. BMJ 2020;371:m4088 http://dx.doi.org/10.1136/bmj.m4088. https://pubmed.ncbi.nlm.nih.gov/33097482/.

5. Second report on progress Prepared by the Independent Panel for Pandemic Preparedness and Response for the WHO Executive Board, January 2021. https://theindependentpanel.org/wpcontent/uploads/2021/01/Independent-

Panel_Second-Report-on-Progress_Final-15-Jan2021.pdf.

6. Alford, R. 1975, Health Care Politics, The University of Chicago Press, Chicago.

7. Alford, R. 1998, The Craft of Inquiry, Theory, Methods, Evidence, Oxford University

8. Sax, S. 1984, A Strife of Interests: Politics and Policies in Australian Health Services, George Allen \& Unwin, North Sydney. Braithwaite, J. Churruca, K. Ellis, LA. Long, J. Clay-Williams, R. Damen, N. Herkes, J. Chiara,P Ludlow, K.(2017). Complexity Science in Healthcare Aspirations Approaches, Applications and Accomplishments: A White Paper. Printed and bound by Macquarie University. ISBN: 9781741384567.

9. Novak B, Eddy M, Bennhold K, et al. Locked-down Europe faces closed borders, economic wounds and dire warnings. New York Times 2020 Mar 18. https://www.nytimes.com/2020/03/18/world/europe/h ungary-borders-europe-coronavirus.html.

10. Ergas, $H$ (2021) 'Official Socialism skulking beneath the cover of Covid.' The Australian published 19th February 2021.

https://www.theaustralian.com.au/commentary/offici al-socialism-skulking-beneath-the-cover-of-

covid/newsstory/2458cb8ad8629258dd2708403e99802a.

11. Albrechtsen, J. (2021) Danger in paradise: we're at risk of being Little Australia. The Weekend Australian Saturday February 20, 2021.

https://www.theaustralian.com.au/inquirer/danger-inparadise-were-at-risk-of-being-little-australia/newsstory/bcca920c6d7e9ffcd819f6fef28024ac.
12. Wong E. Rosenburg M. Barnes, JE (2021) Chinese agents helped spread messages that sowed virus panic in U.S., officials say. New York Times. Updated Jan 5, 2021.

https://www.nytimes.com/2020/04/22/us/politics/coro navirus-china-disinformation.html.

13. The Biology of Belief (2021) @biologyofbeliefs · Health \& Wellness Website with Blanca Estela Castro at https://www.facebook.com/blanca.castro69.

14. Dwyer, JM. (2004). Australian health system restructuring - what problem is being solved? Australia and New Zealand Health Policy 2004, 1:6 doi:10.1186/1743-8462-1-6. 